\title{
Marketing Innovation and Key Performance Indicator in Banking
}

\author{
Marcello Sansone ${ }^{1} \&$ Vincenzo Formisano ${ }^{1}$ \\ ${ }^{1}$ University of Cassino and Southern Lazio, Italy \\ Correspondence: Marcello Sansone, University of Cassino and Southern Lazio, 03043 Cassino - Via \\ Sant'Angelo, loc. Folcara, Italy. E-mail: m.sansone@unicas.it
}

Received: October 20, 2015 Accepted: December 23, 2015 Online Published: January 28, 2016

doi:10.5539/ijms.v8n1p44

URL: http://dx.doi.org/10.5539/ijms.v8n1p44

\begin{abstract}
This paper aims to analyze the relationship between marketing innovation and performance of an enterprise, studying in particular the banking sector. So after a brief review of the literature on services marketing and on the issue of business innovation, through the methodology of the single case (Yin, 1994; Dubois \& Gadde, 2002), that is appropriate because of the complexity of the phenomenon, the research analyzes how innovation of bank management-interpreted as a tendency to integrate strategies and tools of "marketing" that have long been the preserve of industrial production and, in recent years, of retailers - influences the performance and competitive advantages.

In detail, the work provides an analysis of the main KPIs of the bank on the one hand, and innovation indicators of marketing on the other; subsequently it detects any correlation between the two elements and it emphasizes through what strategies a bank has managed to overcome the crisis and to gain a defensible competitive advantage.
\end{abstract}

Keywords: marketing innovation, management innovation, KPI, banks, service marketing, service management

\section{Introduction}

Banking has undergone deep changes even after the growing process of globalization and technological innovation that led it to go beyond the mere function of intermediation towards more evolved forms of financial services, in order to meet the expectations of an increasingly demanding client.

In this context it is important the role of local banks, that though suffering the criticalities arising from the small size, have the advantage of constantly being at the service of the territory, also due to the proximity and the level of deep knowledge, not only in terms economic, but also social and cultural development while respecting the traditions, practices and customs. In fact, it comes to determine a kind of co-evolution of these types of financial intermediaries, associated with the local context of belonging, aimed to increase their competitive advantage, representing the critical resources for the development of each other, in a kind of mutual interdependence. The local bank, in fact, for its localist connotation, mutual principles, social responsibility and for the activity of micro-credit that distinguishes it and allows to combine both internal requirements regarding the spreading risk, and external ones aimed to supporting actors lacking in financial resources, plays an important role in the development of the local social context.

These characteristics are certainly present in the Banca Popolare del Cassinate, recognized as leader in its market segment within such authoritative systemic comparison. It stands out not only for the funds administered and the results that can generate income, but also for the relational capital, organizational flexibility, rapid decision-making, and the mutualistic purpose, social and ethical offer to the territory. The bank has also a clear marketing orientation, even more to the customer, not merely to play a mere activity in this direction. This concept that we're going to analyse in the medium term actually differentiates it in the competition and leads to results that demonstrate the growth of the value created for all its stakeholders. Results are not just about the technical capability of the bank, but also stem from the reputation, fidelity, affection, with respect to which the bank is able to generate the surplus profit. This testifies a basic philosophy that connected to the vision, the characteristics and quality of management, increases through the intangible values also the objective data (KPI). This also improves the effect of local roots, to the point that the bank fails to qualify as a strategic element, as it has the ability to support the institutions in a number of initiatives. 
Based on these considerations, authors aim to identify any elements of the correlation between a number of selected performance indicators and marketing innovation, covering the period 2010-2014.

Therefore, the present work has been structured as follows: after the introduction, it will be a brief review of the literature regarding the marketing of services, innovation and the ability of companies to pursue innovative strategies in relation to the context in order to create value. Then, it will be described the research methodology. Section 5 includes the case study. Finally, in addition to the conclusions, the limits of the study and suggestions for future research will be detailed.

\section{The Role of Service Marketing: Literature Review}

The goal of the work is to measure the relationship between marketing actions and performance in service companies. The importance that the issue of services is increasing in our economic system and again in the place development (Sansone, 2014), makes it useful to make a brief review of the main authors on the subject of service marketing.

The evolution of service marketing literature between 1953 and 1993 can be summarized in three stages (Fisk et al., 1993):

- from 1953 to 1979 , scholars in the service marketing aimed to assert the existence of service marketing science, starting from the definition of concept of "service" and the difference between service and goods (Shostack, 1977);

- during the second stage (1980-1985), the attention of scholar on services shifted from the differences between goods and services, to the implications of these differences on management; for example Lovelock (1983) underlined that literature about service marketing didn't analyze the new marketing practices in the service sector and, for this reason, he proposed a classification of the concept, dividing services on the basis of different marketing treatment needing.

- In the last stage of this classification, service marketing became an established marketing discipline: the researches started to include the heterogeneity of service experience, the control of intangible processes, the management of supply and demand in services, organizational issues and measuring the quality of services (Parasuraman et al., 1988, 1991, 1993; Cronin \& Taylor, 1992; Brown et al., 1993).

An important analysis of literature contributions (46 publications by 33 authors) conducted by Zeithaml, Parasuraman, and Berry in 1985, identified the most cited characteristics of a service during the period 1975-83. The three Authors summarized the service's features in:

intangibility (mentioned by all), inseparability of production and consumption or simultaneity (cited by the great majority), heterogeneity or non standardization (noted by about $70 \%$ ), and perishability or inability to inventory (cited by just over half of the authors).

Another wider research, that included 106 publications during the period 1963-1990, confirm the importance of the features described above, however some relevant characteristics were neglected, for example the absence of ownership in service purchases (Judd, 1964; Rathmell, 1974).

Moreover, some of the most important literature contributions are based on empirical research and analysis: one of the most cited paper is written in 1977 by Shostack - an bank executive-in confirmation that the consideration about service marketing and the characteristics of services are the result of an empirical approach. Therefore, understanding the characteristics of the service, other studies have identified specific marketing problems related to management of service sector; in particular Zeithaml, Parasuraman, and Berry (1985) analyzed eight problems trough an empirical survey for 1000 managers, of which 323 respondents. The result of survey indicate that the biggest problem for services management $(47 \%)$ is demand fluctuation, while the remaining seven variables analyzed are considered problems for much smaller percentages, reflecting the fact that apparently the manager had already internalized the problems related to services management. In order to identify the prospects of development of marketing services - and therefore the literature reference-Fisk et al. (2000) and Brown et al. (2003) asked 10 services experts which are the evolutionary trends of services marketing and they indicate five principles (Furrer, 2004):

- the role of technology in changing services marketing: in particular the scholars underline the impact of internet on service quality and on the way how services are delivered, communicated, sold, and supported.

- $\quad$ customers' expectations for services: for example Berry recognizes that the cultural differences in customer expectations for services are not well understood. Therefore it's necessary a cross-country approach in order to understand how services can be delivered in different, specially because of trade globalization. 
- $\quad$ the importance of services in manufacturing industries: in particular Bowen underlines the importance to understand how enterprises define themselves as service or manufacturing organizations; Gronroos argues that a service-oriented approach will be dominate also in goods marketing.

- $\quad$ the financial quantification of services marketing: most scholars highlight the need to implement further research to understand the impact of marketing services on the results of business performance and to improve measuring the profitability of the services;

- $\quad$ services pricing: also in this case, many scholars indicate the area of the price as a major in which it requires further research by the experts of the service sector.

Analysing the evolution of services marketing, it can observe that when organizations try to improve what makes them successful they go into decline (Schneider, 2000). This assertion is founded on the work of Miller (1990) and Kotter and Heskett (1992): they contend that the reason of the success of services marketing is been observed in itself differentiation in the marketplace: services are different from goods.

This assumption came as a logical result to this conceptual bound. Indeed, Berry (2000) exposes despite that the preponderance of a single area of research - the one in which the Author made major contributions - has essentially interfered with grow in other areas.

Throughout of the 1990s, Literature based the research in service quality measurement and debating the advantages and disadvantages of alternative methodologies.

Schneider and Berry's reference sustained that possibly the gradual appearance during the late 1990s of the Internet was an important business tool and the resulting explosion of interest in e-commerce, the capability for creating new business models, the new ways to transferring information-based services, and new approaches of connecting to customers are originated and sustained by the improvement of Internet technology.

Some Authors asserted that existing service concepts are not readily applicable to Internet services; Brown (2000) suggests that "The ability to obtain and consume services without interacting with a human provider challenges much of our existing knowledge." Also Bowen (2000) affirms: "It now seems that most of what we know about services marketing and management has been derived from the study of face-to-face service encounters or at least over the telephone".

Subsequently Grove, Fisk and John (2003) observe that service marketing confronts many maturing studies. The expansion of service's domain caused the flimsiness of the boundaries that define it, insomuch as, like so many other evolving disciplines, the orientation in which services marketing is directed is unclear.

The brief literature review about the services marketing highlights the complexity of the issue and the need to investigate the phenomenon with an empirical approach.

\section{Innovation as a Key Factor for Bank Survival: A Service-Dominant Logic Approach}

The crucial function played by innovation on both productivity and economic growth has widely been recognized over time by economists, entrepreneurs as well as institutions, starting from the studies of Schumpeter (1942). He underlined how innovation can drive many companies to disappear, were born or reinforce themselves. Innovation appears, thus, as the driver able to create competitive advantage for the enterprise, contributing at the same time to annihilate the competition. The same Schumpeter $(1942 ; 2010)$, in such a perspective, considered this process as "creative destruction", fatal event, cornerstone of capitalism having effect for decades or centuries.

Even more, the changing context conditions characterizing the competitive arena of modern markets require that all socio-economic actors have important ability to adapt. In this view, innovation can be understood as an attempt to preserve their identity over time and makes its value offer sustainable. The ability of the company to understand and even anticipate the contextual changing contingencies (Fiedler, 1967) and market needs, means to be more competitive, successful and enhance their own distinctive characteristics (Ifm, IBM, 2008).

The company that decides to change chooses an interactive relationship with its over-reference systems (Golinelli, 2010; Barile, 2009) that mature expectations over the actions aimed to innovate for a different future, in a logic of evolution (Parente, 2008; Parente \& Petrone, 2010). Such company becomes aware of the paradigm of "no business is an island" (Hakansson \& Snehota, 1995; Gummesson \& Polese, 2009) so that some enterprise, in order to survive, must relate to the environment that surrounds it, respecting constraints, rules and expectations.

The ability to innovate (both incrementally or radically, in process or in product) allows an organization to meet the chance of survival in the long run and helps to make more sustainable its value proposition as being able to constantly adjust their offer in function of the client preferences, favours the creation of a durable competitive advantage. Firm survival in fact implies the persistence of both identity and innovation (Schein, 1990). Therefore 
being able to preserve the value of the offer, means to update appropriately compared to the changing needs and perceptions through a different concept of supply and use of the offer.

In line with the paradigm of the Service-Dominant (S-D) Logic (Vargo \& Lusch, 2004, 2006, 2008, 2009), the concept of value follows the logic of perception and it is therefore subjective of the end user instead of the alternatives on the market.

When a value proposition is preferred to another, through the mechanism of the use, it triggers a process of value co-creation (Prahalad \& Ramaswamy, 2004; Ballantyne \& Varey, 2006; Grönroos, 2008) that involves the multi-actor active contribution of the protagonists of the exchange and the actual value related to a particular offer (up to that time only potential). The focus is towards the process of value creation, in which several parties are involved, and play an active role by taking part in a win-win logic, successful and mutually beneficial. In this framework, the customer is always a co-creator of value. This means that the value is recognized in the moment in which it perceives the service and consumer experience. Thus, it is possible to state that the final product created and sold, just represent the physical, tangible vehicle through which a service is chosen and bought. According to this approach, companies can only make own proposal of value to offer to the market (or value propositions), but the value is actually determined by the final consumer, by his choices/preferences, from the way it makes use of the same product purchased and benefits from the connected service. Capacity of enterprise and consumer needs are driven by an bidirectional relationship, able to generate loyalty and competitive advantage durable in time (Lusch, Vargo, \& O"Brien, 2007).

In other words, the attempt to improve, modify, correct, integrate an offer - that is to innovate - actually brings to build the pillars for the firm survival over time. Innovation becomes today a strategic factor for organizations successfulness, competitiveness (and survival). The reason is that modern organizations are called to understand the market need in order to respect more and more the customer orientation, and his last final judgment on the value proposition offer. This implies that an economy based on service necessarily need to be innovative, customer-oriented and focused on the relationship with client, as the benefits are co-determined (Maglio, Kieliszewski, \& Spohrer, 2010).

As stated by Formisano (2008), in response to increased competition and deep crisis, banks in particular, began to show an active attitude towards customers using the first marketing strategies and realizing the need to shift the strategic and operational focus from product to customer. In highly competitive environments, as modern ones, in order to achieve advantage, great attention should be given to the customer, trying to understand his characteristics and needs, satisfy them promptly by adapting one's range of services (Scott \& Paulotto, 1995).

Due to the general dissatisfaction and mistrust of citizens toward institutions, the customers' trust could represents a goal to be achieved and a value to be preserved, since customers are even more looking for new services (Spohrer, Maglio, Bayley, \& Gruhl, 2007) in the place of the core business of banks. All this have led banks to implement a transition from a product oriented trend to a customer oriented one, with the aim to understand and possibly satisfy the needs of every client. Just to mention one issue of change, bank branches are transforming from operational centers to relational ones. The bank must prove to be fully operational in a few square meters, because the customer, entering into any branch of a bank, judges the entire bank by the impact with the staff, with the structure and the environment. Thus, after a long period of opening new branches in every kind of location, banks have realized the strategic importance in the research of structures with architectural standards consistent with the style of the bank and details of the interior layout in order to make them more functional and consistent with the overall image of the institute and the socio-economic characteristics of the market in which the individual branch operates.

Some examples follow of banking system increasingly oriented towards a new relation with the customer aimed at keeping its loyalty. Bank Credem arranged a corner specialized in providing mortgages and consumer credit, with a layout similar to that of the bank to evoke in the customer's mind the concepts underlying the philosophy of the group; Banca Intesa Sanpaolo increased space dedicated to consulting equipped with desks for the customers; Banca Monte dei Paschi di Siena installed three self-banking positions powered by solar energy; Cassa di Risparmio di Asti: implemented touch screen technology to facilitate consultation and print information leaflets for customers; Cooperative Credit Bank of Carate Brianza created an internal environment characterized by simple geometry, use of high-quality material such as basalt stone and parquet flooring, and colors highlighting the most important areas; Extrabanca created a mechanisms for the customers' entrance, greeted by a staff member who is at his complete disposal, and waiting rooms equipped with coffee machines; Banca Popolare di Milano created an area where customers have the opportunity to interact with the call center, with its network of vendors and with the public administration. 
In line with what said just before, banks top government understood that the quality of banking service is anymore generated by the performance of the product offered, but the performance perceived in relation to the users' expectations. Therefore, to add value to customer service and make it more difficult for competitors to imitate it, banks are extending their services offer. Here, the service provision can be defined as the combination of technical and organizational solutions created and used by the bank to allow customers to use their service (Munari, 1988). The service provision system include contact staff and physical and technological tools, structure organization as for the parts that have an effect on both direct and indirect front-office staff and physical support. The provision of banking services must be designed as a system since considering numerous variables affecting the final level of customer satisfaction.

\section{Research Methodology}

On the basis of the complexity of the issue it is necessary to explain the research methodology adopted. Initially, it was implemented a desk analysis aimed to deepen the national and international academic contributions, in order to outline a framework of interpretation on the subject. Subsequently it was considered appropriate to use the case method (Yin, 2003) that promotes depth analysis of the context of reference (Factor, 2005).

For the acquisition of the information it has been used a research protocol suitable to process data (Yin, 1994; Woodside, 2010). Then it proceeded with the identification, through a theoretical sampling (Patton, 2002), of a single case, selected after analyzing the entire sample of banks belonging to the category of those with medium size (where the class size is derived from the total asset), as part of the study carried out by Milano Finanza and Italia Oggi entitled "L'Atlante delle Banche Leader 2014". This study was also focused on the selection of creditors that have increased steadily in the last three years assets under administration and operating results (revenues, operating profit, ordinary profit and net profit). Based on this criterion, as part of the 590 banks that were included in the sample were selected 316 . These banks were in turn divided into four categories according to total asset:

- Large: 44 banks belong to this area, as they present a volume of total asset 5 billion Euro;

- Medium. In this category are included 66. They are equipped with a volume of total asset between 1 and 5 billion Euros;

- Minor. This size class includes 49 institutions with a volume of total asset between 0.5 and 1 billion Euro;

- Small. In this group are included in 157; they have a volume of total asset of less than 0.5 billion Euro.

Therefore, considered the most suitable with the phenomenon under investigation, the choice fell on Banca Popolare del Cassinate, as it has been recognized leader in its market segment within this authoritative comparison.

In light of this analysis, through the use of multi-method approach the information needed were found to answer the research question using different sources: primary data were acquired in the office of Banca Popolare del Cassinate. By the administrative offices of the bank all the data necessary were acquired to identify any correlation between the key performance indicators (KPI) of the bank and marketing innovation, so as to arrive at the considerations are more qualitative. Therefore, it acquired data for the period 2010-2014 as well as several reports. For more information,, it has been used, such as the website of the bank and recent publications of "Atlas of the leading banks" published by Milano Finanza and Italia Oggi.

Even on the basis of these considerations, it has been identified the key performance indicators (KPIs) to be considered for the analysis.

From those used by Milano Finanza and Italia Oggi for the evaluation of the credit institutions, of medium-sized, able to create value, have been added to those that the purposes of this study were considered worthy of inclusion. Therefore, it selected the following indicators, which will be analyzed with reference to last year and to the last five years:

- $\%$ change total asset

$-\%$ change in net income

- $\%$ change of net banking income

- $\%$ change in operating profit

- $\%$ change of the ordinary income

- \% change ROE

ROE will be measured both in the last year (2013/2014) that as the average of the last five years. 
Will be assessed, however, in each year of period 2010-2014:

- The number of new customers,

- The total number of customers,

- The churn rate,

- The number of customers using more services offered by the bank,

- The number of new branch opening,

- The total number of employees,

- The customer satisfaction.

At a last stage those variables related to innovation in marketing relative to the period 2010-2014 were identified, and expressed in terms of:

- Investments in marketing and communication

- Amount of sponsorships of events organized by the bank

- Investment in brand building BPC

- Amount of sponsorship

- Total number of services offered to customers

- Number of online services offered to customers

- Number of employees assigned to the marketing

- Number of extra-core business activities undertaken.

Finally, it was identified possible elements of correlation between the two types of indicators described, through an approach mostly qualitative.

\section{Analysis of a Single Case: Banca Popolare del Cassinate}

\subsection{Premise}

The reasons which led the authors to select the Banca Popolare del Cassinate as case study, stem from the fact that in 2013 it was ranked first among the largest value creator between small lending institution, while in 2014, it has been included among those of medium size and it was ranked third in the Atlas of the banks. These results, achieved despite the economic crisis, are attributable to a renewed organizational and commercial structure, based on the design of a "new way of banking". This strategy was implemented thanks to the involvement of the whole structure, placing its focus on the management of the relationship with the customer and the organization of the processes of design as well as the dissemination of new products, associated with the research results in terms of dimensional growth of the bank in relation to the structural, financial and economic stability. The BPC, then, over time, with increasing levels, established itself as a national entity systemic able to create value.

\subsection{Genesis and Historical Evolution of Banca Popolare del Cassinate}

The Banca Popolare del Cassinate (BPC), since its foundation in 1955, has highlighted his mutual vocation supporting the reconstruction of the city of Cassino destroyed by the war, and so this has improved the relationship between bank and its place. This connection is the result of an extensive presence exerted by a dense network of branches, that associated with territorial proximity favours the support of numerous initiatives in the economic life of the local community (social, sporting, artistic and cultural). It is precisely the local presence and the constant relationship with the community of reference that constitute the focal point of the mission of this institution lending.

Today, BPC is both the oldest bank in the province of Frosinone and the one counting the highest number of members (1572), set up as a point of reference as well as a strategic element essential to the growth and development of the territory in whose work also supporting local institutions for artistic and cultural excellence. Within the aims pursued by the bank, it can include not only economic goals, nor speculative activities, but rather the ability to reinvest the wealth on the same territory in which it is generated, with the commitment to offer services quality claiming the territory in a qualified way. The bank, thanks to a robust, reliable structure, is always looking for the best solutions to meet the increasingly complex needs of customers. It is able to offer not only the typical services of traditional banks, but also the most innovative asset management, online trading, consulting companies (through agreements and partnerships with specialized institutions), the bank-insurance and tools of payment. To all this it must add the activity of restyling of the branches, which began in 2009, presenting 
characters of innovation and exclusivity, aimed to transmit to stakeholders the philosophy and values that have always characterized the bank. In fact the branches are also used as meeting places and cultural promotion.

\section{Findings and Discussion}

As mentioned in the methodology, the analysis conducted can be summarized in three steps:

1) Analysis of performance and development indicators of the bank;

2) Analysis of the indicators of innovation and marketing;

3) Identification of elements of correlation between the performance indicators and innovations ones, mainly through qualitative analysis.

In reference to the first phase, it is stated that the KPIs analyzed originate from indicators of financial performance and value creation for the place, usually used by MilanoFinanza for classification of banks. However further indicators have been added to these variables, in order to expand the investigation and to make it more comprehensive, computing indicators for development of internal (e.g., employees) and external stakeholder (customers). The Financial KPIs highlight the excellent performance of BPC: just think that $-a s$ anticipated - the Banca Popolare del Cassinate, in 2013 ranked first in Italy among the smaller banks to create economic value, and the third place in 2014 because of the capital administered increase and so the pass to a higher class of BPC.

In particular, the financial indicators are:

- $\%$ change total asset

- $\%$ change in net income

- $\%$ change of net banking income

- $\%$ change in operating profit

- $\%$ change of the ordinary income

- $\%$ change ROE

For each one, percent change it was calculated in reference to last year (2014/2013) (Table 1) and to the last five years $(2010 / 2014)$ (Table 2).

Table 1 . KPI \% change 2013/2014

\begin{tabular}{ll}
\hline & $\%$ CHANGE 2013/2014 \\
\hline Total asset & $11,83 \%$ \\
Net income & $14,81 \%$ \\
Net banking income & $25,92 \%$ \\
Operating profit & $2,75 \%$ \\
Ordinary income & $7,19 \%$ \\
\hline
\end{tabular}

Source: Author's elaboration.

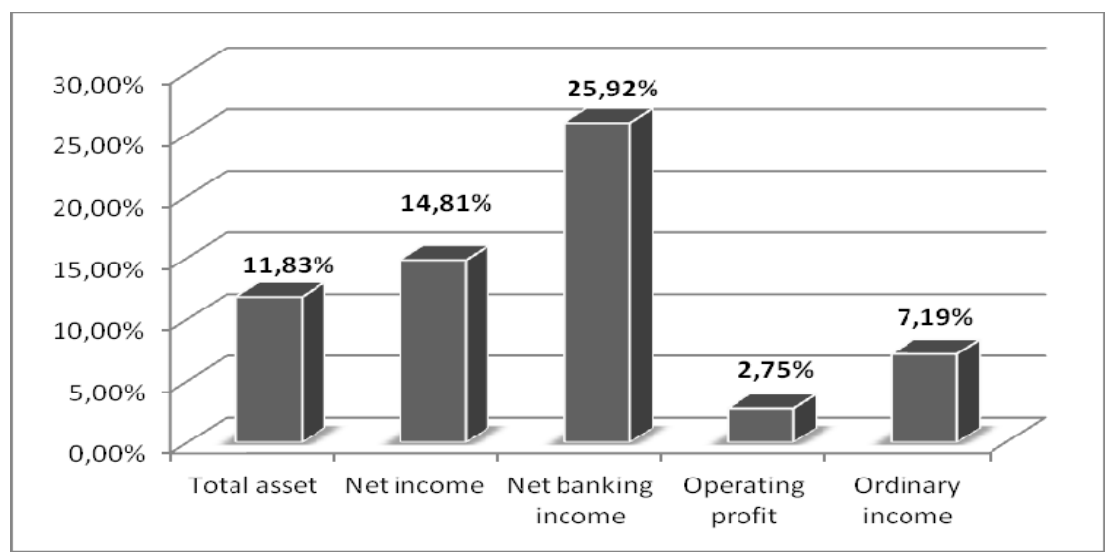

Figure 1. KPI \% change 2013/2014 
Table 2. KPI \% change 2010/2014

\begin{tabular}{ll}
\hline & \% change 2010-2014 \\
\hline Total asset & $138,80 \%$ \\
Net income & $128,01 \%$ \\
Net banking income & $145,50 \%$ \\
Operating profit & $174,64 \%$ \\
Profit & $189,05 \%$ \\
\hline
\end{tabular}

Source: Author's elaboration.

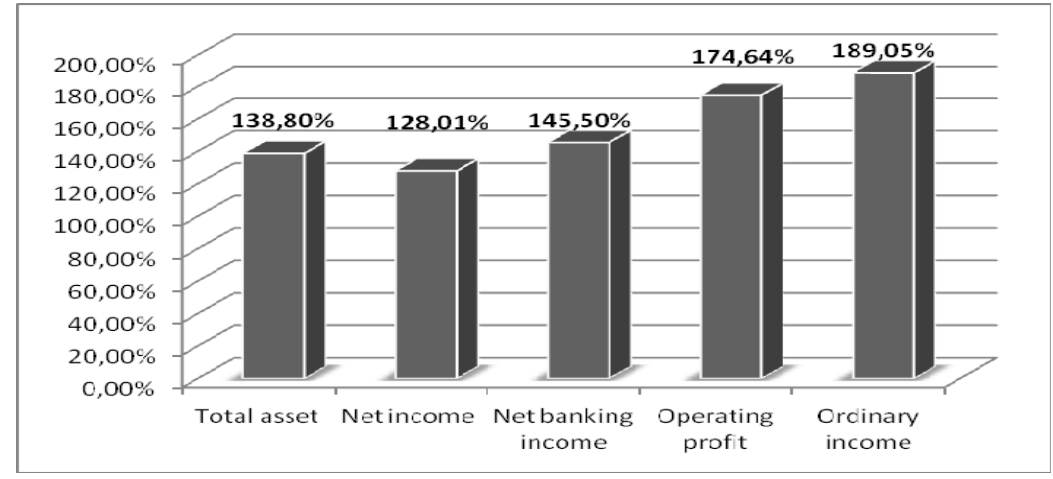

Figure 2. KPI \% change 2010/2014

The analysis of financial indicators shows the very positive performance of the bank: in fact the total asset increases by $11.83 \%$ in the last year and $138.80 \%$ over the five years; net income is the balance of the income statement, that the profit or loss declared in the budget; it grew by $14.81 \%$ in 2014 compared to 2013 , and $128 \%$ over the period.

The third KPI is the net banking income: once again the data shows a steady growth and consistent, $25.92 \%$ in 2014 and $145.50 \%$ in the period of reference.

Again, operating profit of BPC has increased by $174.64 \%$ from 2010 to the present, and only 2.75 in 2014 . Finally typical profit grew by $7.19 \%$ in 2014 and $189.05 \%$ in the last five years.

The last indicator considered by Milano Finanza is ROE (Table 3), whose relevance is undeniable: it shows the highest rate in $2012(8.30 \%)$, however, the index is constant and very positive.

Table 3. Trend in ROE 2010/2014

Source: author's elaboration.

\begin{tabular}{llllll}
\hline & 2010 & 2011 & 2012 & 2013 & 2014 \\
\hline ROE & $5,64 \%$ & $6,09 \%$ & $8,30 \%$ & $7,32 \%$ & $7,81 \%$ \\
\hline
\end{tabular}

In order to broaden the context of performance analysis and development of the bank, will also analyze indicators inclusive of consumer satisfaction and the acquisition or churn of customers. In particular:

- Number of new customers every year,

- Total number of clients,

- Total number of customers who use more services,

- Churn rate

- Customer satisfaction 
Table 4. Marketing KPI 2010/2014

\begin{tabular}{llllll}
\hline & 2010 & 2011 & 2012 & 2013 & 2014 \\
\hline New customer $\mathrm{n}$. & 2.263 & 2.475 & 2.861 & 3.125 & 3.483 \\
Total customer $\mathrm{n}$. & 20.503 & 22.210 & 24.221 & 29.132 & 32.615 \\
Customers using more services n. & 30.496 & 33.598 & 36.639 & 40.016 & 42.953 \\
\hline
\end{tabular}

Source: Author's elaboration.

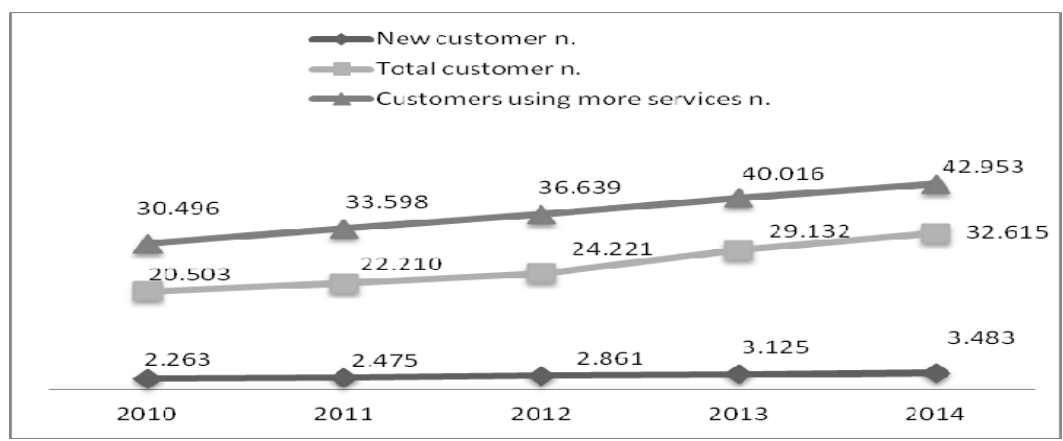

Figure 3. Marketing KPI 2010/2014

While these indicators show the positive performance of the BPC: the rate of new customer acquisition-hence the total number of customers - and the number of customers using an integrated system of services recorded a growth decidedly high: the annual number of new clients is growing and in the five years between 2010 to 2014 the total number of customers increased by more than $59 \%$, while number of customers using an integrated system of services increased by $40.85 \%$ in five years (Table 4 ).

Also annually the bank's management calculates the customer satisfaction served (only available until 2013), it is almost stable over the years (Table 5).

Table 5. Customer satisfaction 2013/2010

\begin{tabular}{lllll}
\hline & 2010 & 2011 & 2012 & 2013 \\
\hline Customer Satisfaction & 69 & 72 & 72 & 73 \\
\hline
\end{tabular}

Source: Author's elaboration.

Likewise, also the rate of customer churn remains almost unchanged over the years around 6\%. (Tab. 6.) Also this indicator is significant positive performance of the company, whether in context of the economic crisis, the number of business bankruptcies and thus the closures of the bank account.

Table 6. Churn rate 2014/2010

\begin{tabular}{llllll}
\hline & 2010 & 2011 & 2012 & 2013 & 2014 \\
\hline Churn rate & $5,40 \%$ & $5,95 \%$ & $6,05 \%$ & $6,15 \%$ & $6,26 \%$ \\
\hline
\end{tabular}

Source: Author's elaboration.

The total number of employees and the number of opening new branches have been included among the indicators of the bank's development: both of the details are to be found almost throughout the years. The largest number of branches was opened in 2011 (no. $=6$ ), in the following years the number has stabilized at 2 and finally 1 in 2014. The number of employees totalled 127 in 2010, around the figure of 150 in last three years. These data appear to be even more significant if contextualized to the current macro economic variables, in particular the period of crisis that characterizes the economic system, the rate of unemployment and layoffs.

On the other hand, the authors analyzed the variables that can synthesize the marketing policies and marketing innovation of the bank, through: 
- Analysis of financial statements, for example include the amount of investments by the bank to the strategies of marketing and communication,

- Management interviews and surveys on the territory, in order to detect the initiatives of sponsorship, organization of events, number of activities outside the core business.

In detail:

- Investments in marketing and communication

- $\quad$ Amount of sponsorships of events organized by the bank

- Investment in brand building BPC

- $\quad$ Amount of sponsorship

- Total number of services offered to customers

- $\quad$ Number of online services offered to customers

- $\quad$ Number of employees assigned to the marketing

- Number of extra-core business activities undertaken.

Table 7. Marketing innovation indicators 2014/2010

\begin{tabular}{|c|c|c|c|c|c|}
\hline k/euro & 2010 & 2011 & 2012 & 2013 & 2014 \\
\hline Investments in marketing and communication & 752 & 813 & 871 & 905 & 914 \\
\hline Amount of sponsorships of events organized by the bank & 102 & 121 & 135 & 149 & 152 \\
\hline Amount of sponsorship & 247 & 300 & 470 & 274 & 367 \\
\hline Investment in brand BPC building & 70 & 91 & 108 & 120 & 99 \\
\hline
\end{tabular}

Source: Author's elaboration.

Early indicators reported (Table 7) show the continued commitment of the BPC to invest in marketing and communication (for a total of 914,000 in 2014), both through direct organization of events ( $€ 152,000$ in 2014) and through sponsorship of various activities ( $€ 367,000$ in 2014). In addition, the management of the bank under analysis shows an increasing attention in the construction of a real brand "BPC" that is clear and well recognizable by the consumer.

Moreover, from the intersection of the amount of investments in branches, internal layout and equipment, and among the survey carried out within the shop, there is a clear willingness of the bank to focus on the physicality and the internal layout as an added value for the customer. The innovation of the banking therefore shifted towards a customer-centric approach, outlining a concept that aims primarily relational aspect, placing the bank-customer interaction as the centrepiece of the new agency model; today branches appear more friendly due to exceeding the formalities before the relational characterized.

The most important aspect in terms of marketing innovation is linked to the policies of brand extension: brand BPC building proves so strong that the bank has managed to diversify their activities outside the core business, conveying the awareness and loyalty built over the years. The ultimate expression of these activities is reflected in the opening of BPC Coffee, BPC Baby area and point shop (Cassino) in 2009; flagship store and multimedia museum in 2013 and BPC Coffee, BPC Baby area and point shop (Frosinone). In any case the bank doesn't neglect the main activities: from 2010 to 2014 the services offered to the consumer increased from 140 to 152 , those on-line from 1 to 7.

So there was a growing concern for the primary and secondary stakeholders that results in a constant and increasing investment in marketing; on the other hand the economic performance finance and development are decidedly positive even in a period of crisis, trading down consumption and strong distrust of institutions, even those banks.

It should be noted, therefore, the will-followed by concrete strategies - and the ability of the management of the BPC to build a new model of banking, not only in the payoff, which is the main factor of success and competitive advantage. This process of marketing innovation of BPC originates from the manifest and especially latent needs of consumer: in a time when many writers and practitioners speak of de-materialization of the instruments and the physical space of the bank itself, BPC works for build a business model centred on the nearby to customer, both physically and empathically. The BPC constructs a relational concept of proximity to 
the customer who appears to be winning. Obviously this does not reduce the importance of the tools of e-banking, which, as we have seen, are an indispensable element of innovation in services; however, BPC management believes that they cannot replace the physicality of the branches, especially for more complex services. In particular, the branches have been refurbished with an innovative format that combines physical and virtual, in an environment where you feel the centrality and proximity to customers.

The marketing innovation described shows that BPC has developed its brand and continues to invest on its improvement, beyond the view of marketing as an area of cost and leading marketing strategies and customer care as drivers exceeded the economic crisis. It has managed to reach positive KPIs and create value for all stakeholders.

\section{Conclusions}

The present study was aimed to investigate the relationship between the processes of marketing innovation and business performance, in particular focusing on the banking sector.

Through the methodology of the single case study, the case of BPC has been chosen because of economic, human and fiduciary asset that makes significant the investigation.

So, after a brief review of the literature on marketing and service innovation, the performance and development indicators, the indicators of innovation marketing have been described and analyzed; finally possible elements of correlation between the two types of indicators are been identified.

The analysis shows that the BPC has developed over time a bank model innovative and able to achieve lasting competitive advantages and defensible. In fact, the economic performance of the last five years appear to be positive despite the economic crisis and the widespread sense of distrust of consumers against companies banking: ordinary and net profits, operating profit, ROE, total assets under, the number of customers, the number of new customers per year increase, compared with a growing focus on the customer, which translates to investments in marketing and communication, brand building BPC, in the activities of sponsorship and event organization.

Investments on the naming of the bank, the logo, the colours used, on restructuring of branches and opening of new shops, sponsorship of cultural and sporting events are not sporadic activities and mere communication tools but integrated in a precise marketing planning. The strength of the brand is confirmed by the possibility of extending the brand: the opening of the BPC Cafè and the flagship store show that the bank has managed to create a brand replicable in extra core activities and its ability to create value for stakeholders of territory.

In conclusion, through quantitative analysis, it is shown that a local bank has overcome the economic crisis through marketing innovation and a customer centric model, the BPC becomes a relevant territorial actor and it supports policy makers and economic development of place.

The paper turns out to have the limitations associated with the methodology used, since the generalization of considerations resulting from the study of a single case, can sometimes be questionable, considering the role of the specific context and local stakeholders on the process of development of the sector services. However, as anticipated, this method appears to be consistent and adequate to investigate of phenomena still poorly studied and formalized, such as the one in question.

It is interesting, in future research to test the repeatability of the BPC model and thus replicate the analysis in other contexts characterized by different macro and micro economic variables.

\section{References}

Ballantyne, D., \& Varey, R. J. (2006). Creating value-in-use through marketing interaction: the exchange logic of relating, communicating and knowing. Marketing Theory, 3, 335-348. http://dx.doi.org/10.1177/1470593106066795

Barile, S. (2009). Management Sistemico Vitale. Giappichelli, Torino.

Bowen \& David, E. (2000). [Part 4]. In R. P. Fisk, S. J. Grove, \& J. John (Eds.), Services Marketing Self-Portraits: Introspections, Reflections, and Glimpses from the Experts (pp. 37-51). Chicago, American Marketing Association.

Brown, S. W. (2000). [Part 4]. In R. P. Fisk, S. J. Grove, \& J. John (Eds.), Services Marketing Self-Portraits: Introspections, Reflections, and Glimpses from the Experts (pp. 52-69). Chicago: American Marketing Association. 
Brown, T. J., Churchill, G. A., \& Peter, J. P. (1993). Improving the measurement of service quality. Journal of Retailing, 69(1), 127-139. http://dx.doi.org/10.1016/s0022-4359(05)80006-5

Cronin, J. J. Jr, \& Taylor, S. A. (1992). Measuring service quality: a reexamination and extension. Journal of Marketing, 56(3), 55-68. http://dx.doi.org/10.2307/1252296

Dubois, A., \& Gadde, L. E. (2001). Case studies in business market research. In A. Woodside (Ed.), Handbook of business marketing research. Advances in marketing and purchasing. Cambridge: JAI Press.

Fiedler, F. E. (1967). A Theory of Leader Effectiveness. New York: McGraw-Hill.

Fisk, R. P., Brown, S. W., \& Bitner, M. J. (1993). Tracking the evolution of the service marketing literature. Journal of Retailing, 69(1), 60-103. http://dx.doi.org/10.1016/s0022-4359(05)80004-1

Fisk, R. P., Grove, S. J., \& John, J. (2000). Services marketing self-portraits: introspections, reflections, and glimpses from the experts. American Marketing Association, Chicago.

Formisano, V. (2002). La dinamica evolutiva dell'impresa bancaria: una lettura in chiave sistemico-vitale. Dimensione, teoria delle risorse, network, Quaderno n. 19, Dipartimento Impresa e Lavoro, Università degli Studi di Cassino.

Formisano, V. (2008). Il network bancario quale risposta alle esigenze della PMI, in G. Birindelli, M. Modina, a cura di, Imprese, banche e finanza. Le evidenze di un'analisi territoriale alla luce della crisi finanziaria, Franco Angeli, pp. 139-162.

Formisano, V., Modina, M., \& Birindelli, G. (2009). Rapporto Banca-Impresa, Franco Angeli.

Furrer, O. (2004). Services marketing self-portraits: introspections, reflection and glimpses form experts. Int $J$ Serv Ind Manage, 14(1), 148-151. http://dx.doi.org/10.1108/ijsim.2003.14.1.148.1

Golinelli, G. M. (2010). Viable Systems Approach - Governing Business Dynamics. Kluwer (Cedam), Padova.

Grönroos, C. (2008). Adopting a service business logic in relational business-to-business marketing: value creation, interaction and joint value co-creation. Proceedings of the Otago Forum, 2, 269-287.

Gummesson, E., \& Polese, F. (2009). B2B is not an island! Journal of Business \& Industrial Marketing, 24(5).

Hakansson, H., \& Snehota, I. (1995). Developing relationship in business network. London: Routledge. http://dx.doi.org/10.1108/08858620910966228

IFM, IBM. (2008). Succeeding through Service Innovation: A Service Perspective for Education, Research, Business and Government. University of Cambridge Institute for Manufacturing, Cambridge, UK.

Judd, R. C. (1964). The Case for Redefining Services. Journal of Marketing, 28(1), 58-59. http://dx.doi.org/10.2307/1249228

Kotter, J. P., \& Heskett, J. L. (1992). Corporate Culture and Performance. New York: The Free Press.

Lovelock, C. H. (1983). Classifying services to gain strategic marketing insights. Journal of Marketing, 47, 9-20. http://dx.doi.org/10.2307/1251193

Lusch, R. F., Vargo, S. L., \& O’Brien, M. (2007). Competing through service: Insights from service-dominant Logic. Journal of Retailing, 83, 5-18. http://dx.doi.org/10.1016/j.jretai.2006.10.002

Maglio, P. P., Kieliszewski, C. A., \& Spohrer, J. C. (2010). Service Science: Research and Innovations in the Service Economy. Handbook of Service Science, Springer, New York.

Maglio, P. P., Srinivasan, S., Kreulen, J. T., \& Spohrer, J. (2006). Service systems, service scientists, SSME, and innovation. Communications of the ACM, July, 49(7), 81-85. http://dx.doi.org/10.1145/1139922.1139955

Miller, D. (1990). The Icarus Paradox. New York: Harper Business.

Munari, L. (1988). Differenziazione dell'offerta e segmentazione della domanda di servizi bancari. Giuffrè, Milano.

Parasuraman, A, Zeithaml, V. A., \& Berry, L. L. (1988). SERVQUAL: a multiple-item scale for measuring consumer perceptions of service quality. Journal of Retailing, 64(1), 12-40.

Parente, R. (2008). Co-Evoluzione e Cluster Tecnologici. Aracne Editrice, Roma.

Parente, R., \& Petrone, M. (2010). Strategie di Co-Evoluzione nei sistemi locali innovativi. Sinergie, 83, 31-52.

Prahalad, C. K., \& Ramaswamy, V. (2004). The future of competition: Co-creating unique value with customers. Cambridge: Harvard University Press. http://dx.doi.org/10.5860/choice.41-6635 
Rathmell, J. M. (1974). Marketing in the Service Sector. Cambridge, MA: Winthrop.

Sansone, M. (2012) Place Management: città, territori, marketing. Milano: Mc-Graw-Hill.

Sansone, M. (2014). Value creation in place management: The relevance of Service Providers. International Journal of Management Sciences and Business Research, 3(11), 13-19.

Sansone, M., \& Bruni, R. (2013). Involving City Authorities in Event Planning. Scienze Regionali - Italian Journal of Regional Science Articles, 12(1), 115-124.

Schein, E. H. (1990). Cultura d'azienda e leadership. Guerrini e Associati, Milano.

Schneider, B. (2000). [Part 9]. In R. P. Fisk, S. J. Grove, \& J. John (Eds.), Services Marketing Self-Portraits: Introspections, Reflections, and Glimpses from the Experts (pp. 173-187). Chicago: American Marketing Association.

Schumpeter, J. A. (1942). Capitalism, socialism, and democracy. New York: Harper \& Row.

Schumpeter, J. A. (2010). Il capitalismo può sopravvivere? La distruzione creatrice e il futuro dell'economia globale. Etas, Milano.

Scott, W. G., \& Paulotto, M. (1995). L'evoluzione del concetto di marketing bancario. In W. G. Scott (Ed.), Manuale di Marketing bancario. Utet, Torino.

Shostack, G. L. (1977). Breaking free from product marketing. Journal of Marketing, 41(1), 73-80. http://dx.doi.org/10.2307/1250637

Spohrer, J., Maglio, P. P., Bailey, J., \& Gruhl, D. (2007). Steps toward a Science of Service Systems. Computer, 71-77. http://dx.doi.org/10.1109/mc.2007.33

Vargo, S. L., \& Lusch, R. F. (2004). Evolving to a new dominant Logic for marketing. Journal of Marketing, 68, $1-17$.

Vargo, S. L., \& Lusch, R. F. (2006). Service-Dominant Logic: What It Is, What It Is Not, What It Might Be. In R. F. Lusch \& S. L. Vargo (Eds.), The Service-Dominant Logic of Marketing: Dialog, Debate, and Directions (pp. 43-56). ME Sharpe, Armonk.

Vargo, S. L., \& Lusch, R. F. (2009). A service-dominant logic for marketing. In VV.AA. (Eds.), The Sage Handbook of Marketing Theory (pp. 219-234). London, UK: Sage.

Vargo, S. L., Maglio, P. P., \& Akaka, M. A. (2008). On value and value co-creation-A service systems and service logic perspective. European Management Journal, 26(3), 145-152. http://dx.doi.org/10.1016/j.emj.2008.04.003

Yin, R. (1994). Case study research: Design and methods (2nd ed.). Thousand Oaks, CA: Sage Publishing.

Yin, R. K. (2003). Case study research: Design and methods (3rd ed.). Thousand Oaks, CA: Sage.

Zeithaml, V. A., Berry, L. B., \& Parasuraman, A. (1996). The behavioral consequences of service quality. Journal of Marketing, 60(2), 31-46. http://dx.doi.org/10.2307/1251929

Zeithaml, V. A., Parasuraman, A., \& Berry, L. L. (1985). Problems and strategies in services marketing. Journal of Marketing, 49(2), 33-46. http://dx.doi.org/10.2307/1251563

Zeithaml, V. A., Parasuraman, A., \& Malhotra, A. (2002). Service quality delivery through websites: a critical review of extant knowledge. Journal of the Academy of Marketing Science, 30, 362-375. http://dx.doi.org/10.1177/009207002236911

Zhang, J., Beatty, S. E., \& Walsh, G. (2005). Cross-cultural services research: a review of the literature and future research directions. In L. Huff \& S. M. Smith (Eds.), Proceedings of the 10th Cross Cultural Research Conference (pp. 11-14), Puerto Rico, December. http://dx.doi.org/10.1016/j.jbusres.2007.06.003

\section{Note}

Note 1. Although this paper represents the result of communal considerations of the Authors, the paragraphs 3, 4, 5 have been elaborated by Formisano V., the paragraphs 2, 6 have been elaborated by Sansone M.

\section{Copyrights}

Copyright for this article is retained by the author(s), with first publication rights granted to the journal.

This is an open-access article distributed under the terms and conditions of the Creative Commons Attribution license (http://creativecommons.org/licenses/by/3.0/). 